\title{
CIALO LUDZKIE I JEGO UDZIAŁ W SZCZĘŚCIU NIEBA - KONCEPCJA PSEUDO-DIONIZEGO AREOPAGITY WOBEC POGLĄDÓW NEOPLATONIKÓW POGAŃSKICH
}

Postać Pseudo-Dionizego Areopagity wydaje się nie zajmować szczególnie ważnego miejsca pośród wczesnochrześcijańskich autorów, którzy próbowali stworzyć chrześcijańską antropologię filozoficzną i teologiczną. Nie napisał on żadnego traktatu na temat natury człowieka, a fragmenty jego pism odnoszące się do wzajemnych relacji duszy i ciała to bardzo nieznaczna część jego twórczości. Mimo to, te nieliczne fragmenty są bardzo ciekawe, ponieważ jego pisma zawierają konfrontację z najpóźniejszą postacią pogańskiego neoplatonizmu, który rozwinął się w ateńskiej szkole neoplatońskiej. Szkoła ta, co warto przypomnieć, została wskrzeszona pod koniec IV w. po Chr. przez Plutarcha z Aten. Choć w Atenach zawsze studiowano Platona, to jednak wydaje się, że to właśnie Plutarch nadał tej szkole charakter, który zachowała aż do zamknięcia jej w 529 r. Przez większą część V w. kierownikiem szkoły (diadochem) był Proklos - ostatni wielki pogański filozof $f^{1}$.

Obecnie większość autorów badających dzieła Pseudo-Dionizego Areopagity zdaje się przychylać do tezy, że on sam także był neoplatońskim filozofem przed swoim nawróceniem na chrześcijaństwo. Choć tożsamość tego autora ciaggle pozostaje nieznana, to jego pisma zdradzają głęboki związek z poglądami, które pielęgnowano właśnie w Szkole Ateńskiej² ${ }^{2}$ Dlatego też czasem nazywa się Pseudo-Dionizego chrześcijańskim Proklosem ${ }^{3}$. Po swoim nawróceniu Pseudo-Dionizy już jako chrześcijanin konfrontuje się ze swoimi wcześniejszymi poglądami. W niniejszych rozważaniach chciałbym wykazać, że ma on pełną świadomość nie tylko czerpania z pogańskiego dziedzictwa, ale także dokładnie wie, w którym miejscu nie zgadza się ono z nauką chrześcijańską i dlatego należy je odrzucić.

* Ks. dr hab. Tomasz Stępień, prof. UKSW - kierownik Katedry Filozofii Religii w Instytucie Dialogu Kultury i Religii na Wydziale Teologicznym Uniwersytetu Kard. Stefana Wyszyńskiego wWarszawie; e-mail: t.stepien@uksw.edu.pl.

${ }^{1}$ Por. A. Louth, Denys the Areopagite, London 1989, 37.

${ }^{2}$ Por. S. Klitenic Wear - J. Dillon, Dionysius the Areopagite and the Neoplatonist Tradition. Despoiling the Hellens, Ashgate 2006, 3-4.

${ }^{3}$ Por. W. Beierwaltes, Platonizm w chrześcijaństwie, thum. P. Domański, Kęty 2003, 42. 
1. Poglądy bezbożników. W ostatnim siódmym rozdziale traktatu Hierarchia kościelna Pseudo-Dionizy omawia ceremonię pogrzebu. Opis ten jest chyba jednym z najkrótszych przedstawień obrzędów liturgicznych Kościoła, jaki prezentuje nam autor. Jednak, co istotne, niejako przy okazji Pseudo-Dionizy przeciwstawia się „profanom”, dla których obrzęd ten musi wydawać się śmieszny:

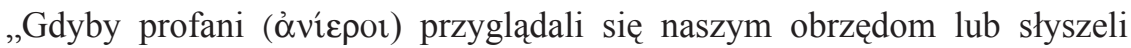
o nich, z pewnością, jak sądzę, uznaliby je za bardzo śmieszne i użalaliby się nad naszymi wymysłami. Nie powinno nas to jednak dziwić, skoro jest powiedziane w Piśmie, że «ci, którzy nie uwierzą również nie będą w stanie zrozumieć» (Iz 7, 9). My zaś doskonale pojmujemy duchowe znaczenie tych świętych rytów, od kiedy Jezus zesłał na nas swoje oświecenie"4.

Jeszcze jaśniej Pseudo-Dionizy wyraża się na początku tego rozdziału, kiedy to krytycznie pisze o poglądach owych bezbożników:

„Jeżeli zaś chodzi o profanów, to jedni z nich bezrozumnie sądzą, że czeka ich zupełne unicestwienie, drudzy - że nastąpi zerwanie powiązań ciał z ich duszami, ponieważ, jak twierdzą, ta więź nie może trwać dalej w warunkach boskiego życia i w stanie boskiej szczęśliwości. Oni i nie rozumieją tych rzeczy, i nie zostali dostatecznie wprowadzeni w tę boską wiedzę, zgodnie z którą to sam Chrystus dostarczył nam wzoru życia o najbardziej boskim wymiarze. Są też tacy, którzy uważając, że dusze będą mogły łączyć się z innymi ciałami, głoszą w ten sposób, jak sądzę, fałszywe wyobrażenia o ciałach, które towarzyszyły świętym duszom $w$ ich doczesnych zmaganiach, niegodnie odmawiając im nadprzyrodzonych nagród, czekających na nich u kresu ich boskich zmagań. Inni znowu, rozumując, nie wiem z jakiej przyczyny, materialistycznie, mówią, iż najbardziej uświęcony spokój doskonałej szczęśliwości, obiecany świętym, odpowiada poziomowi naszego ziemskiego życia i bezbożnie twierdza, że ci, którzy stali się równi Aniołom, posilają się pokarmem właściwym dla życia podlegającego zmianie"s.

Nie sposób nie dostrzec w powyższym fragmencie, że Pseudo-Dionizy daje przegląd poglądów pogańskich szkół filozoficznych na temat relacji duszy i ciała oraz tego, co z ciałem dzieje się po śmierci. Ci, którzy „bezrozumnie sądza, że czeka ich zupełne unicestwienie", to z pewnością epikurejczycy. Jako drugi pogląd Pseudo-Dionizy wymienia tych, którzy sądzą że „nastąpi zerwanie powiązań ciał z ich duszami, ponieważ, jak twierdza, ta więź nie może trwać dalej w warunkach boskiego życia i w stanie boskiej szczęśliwości”.

${ }^{4}$ Pseudo-Dionysius Areopagita, De ecclesiatica hierarchia VII 3, 1, 556D-557A, ed. G. Heil - A.M. Ritter, w: Pseudo-Dionysius Areopagita, Corpus Dionysiacum II, Patristische Texte und Studien 36, Berlin 1991, 122-123, thum. M. Dzielska, w: Pseudo-Dionizy Areopagita, Pisma teologiczne, Kraków 2005, 205.

${ }^{5}$ Tamże VII 1, 2, 533B-C, ed. Heil - Ritter, s. 121, tłum. Dzielska, s. 203. 
Taki pogląd spotykamy w zasadzie w większości szkół nawiązujących do szeroko rozumianego platonizmu, jak również w szkołach pitagorejskich. Trzeci pogląd, który zostaje odrzucony, to metempsychoza, ponieważ chodzi o tych, którzy twierdzą, że „,dusze będą mogły łączyć się z innymi ciałami”. Pogląd ten był również przyjmowany $\mathrm{w}$ szkołach platońskich. Ostatnie twierdzenie, któremu także Pseudo-Dionizy się sprzeciwia, to przekonanie, że życie po śmierci będzie wyglądało dokładnie tak jak życie ziemskie. Przyznam, że nie znalazłem szkoły filozoficznej, która dokładnie taki pogląd by głosiła. Oczywiście epikurejczycy głosili, że życie szczęśliwe, jedyne jakie człowiekowi jest dane, to właśnie to, które przeżywamy na ziemi ${ }^{6}$. Podobne akcenty możemy znaleźć też u stoików ${ }^{7}$. Jednak, jak to zobaczymy, pogląd ten może być odpowiedzią na zarzuty przeciwko zmartwychwstaniu ciał, które przeciw chrześcijanom wysuwali pogańscy neoplatonicy.

2. Niejednolitość neoplatońskiej nauki na temat ciała. Skoro Pseudo-Dionizy wyraźnie odwołuje się do poglądów filozofów pogańskich bliskiego mu nurtu neoplatońskiego, to aby zrozumieć właściwie wymowę jego polemiki, należy przyjrzeć się temu, co rzeczywiście filozofowie (zwłaszcza ci ze Szkoły Ateńskiej) twierdzili na temat ludzkiego ciała. W tej materii panuje ciagle wiele nieporozumień ponieważ, jak zobaczymy, stosunek do ciała w łonie samego neoplatonizmu pogańskiego jest niejednolity. Jednocześnie analiza pogańskich twierdzeń na ten temat pozwoli nam lepiej ująć to, co przynosi chrześcijaństwo i w czym chrześcijańskie orędzie naprawdę różni się od prezentowanego przez Greków.

Zanim jednak przejdziemy do poglądów samych filozofów trzeba w tym miejscu poczynić ważną uwagę. W czasach Pseudo-Dionizego, czyli najprawdopodobniej w drugiej połowie V w. po Chr., nie możemy już mówić o szkołach filozoficznych we wcześniejszym wymiarze. Jeszcze w II w. i 1. poł. III w. istniało wiele szkół filozoficznych. Możemy tu mówić o epikurejczykach, stoikach (także cynikach), pitagorejczykach, perypatetykach i oczywiście platonikach. Jednak już w 2. poł. III w. obserwujemy stopniowe zanikanie różnorodności szkół filozoficznych. Było to na pewno związane z faktem, że rodzący się wtedy neoplatonizm był w istocie syntezą większości poglądów wcześniejszych filozofów ${ }^{8}$. Choć nie możemy powiedzieć, że zasymilował on poglądy epikurejskie, to na pewno w skład neoplatońskiej syntezy wszedł dominujący w niej platonizm (medioplatonizm), poglądy perypatetyków, stoików i neopitagorejczyków, jak również przekonania zaczerpnięte ze wschodnich nurtów,

\footnotetext{
${ }^{6}$ Por. G. Reale, Historia filozofii starożytnej, thum. E.I. Zieliński, t. 3, Lublin 1999, 263-264.

${ }^{7}$ Por. tamże, s. 408.

${ }^{8}$ Zwracam na to uwagę w moim opracowaniu: T. Stępień, Pseudo-Dionizy Areopagita chrześcijanin i platonik. Polemiczne aspekty pism ,Corpus Dionysiacum” w kontekście mowy św. Pawta na Areopagu (Dz 17, 22-31), Warszawa 2010, 21.
} 
które znalazły swój wyraz w Wyroczniach chaldejskich i Pismach hermetycz$n y c h^{9}$. W IV w. mamy już do czynienia w zasadzie tylko z neoplatonikami, którzy uprawiali filozofię $\mathrm{w}$ różnych ośrodkach i nieznacznie różnili się od siebie poglądami. Wśród tych szkół możemy wyróżnić założony jeszcze przez Plotyna kragg neoplatoników w Rzymie oraz szkoły, wśród których najważniejsze znaczenie miały: Apamea, Pergamon i od końca IV w. Ateny ${ }^{10}$.

Nauczanie w szkołach neoplatońskich polegało głównie na lekturze i komentowaniu tekstów filozoficznych. Na początku czytano Arystotelesa, jako tego, który najlepiej ujął sprawy związane ze światem podksiężycowym. Na wyższym poziomie czytano już mistrza, który był niedościgniony w przedstawianiu tego, co ponadzmysłowe - Platona. Istotą filozofii neoplatońskiej było specyficzne czytanie i komentowanie Platona. Warto więc nasze rozważania na temat poglądów neoplatoników zacząć od tego, jak odczytywali oni jego poglądy dotyczące wzajemnych relacji duszy i ciała.

Przyzwyczailiśmy się do tego, aby traktować poglądy Platona w tej materii w sposób jednoznaczny ${ }^{11}$. Większość opracowań odwołuje się tutaj do jego wczesnych i średnich dialogów, w których stwierdza, że ciało jest więzieniem i grobem duszy, a sama filozofia polega na ćwiczeniu się w śmierci i wyrywaniu duszy z ciała, które przeszkadza jej w osiągnięciu szczęścia ${ }^{12}$. Wiązało się z tym nauczanie Platona o metempsychozie. Dusza, która po śmierci doszła do oglądania idei i szczęścia musiała po upływie jakiegoś czasu (10 tys. lat) wcielić się ponownie po wypiciu wody z rzeki zapomnienia. W ten sposób dusza znów musiała ulec znacznemu ograniczeniu swoich możliwości poznawczych, co Platon nazywa „odpadnięciem skrzydeł"13. Wszystkie te poglądy niewątpliwie są obecne w dialogach Platona, tyle, że głównie w dialogach

${ }^{9}$ Widać to już w samej postawie Plotyna, którą zajął wobec wcześniejszych filozofów, por. Reale, Historia filozofii starożytnej, t. 4, Lublin 1999, 487-489.

${ }^{10}$ Por. tamże, s. 618-622.

${ }^{11}$ Najlepszym przykładem jest tutaj klasyczne opracowanie G. Reale, który omawiając poglądy Platona twierdzi, że w zasadzie dodał jedynie ontologiczne podstawy do Sokratejskiego twierdzenia, że „człowiekiem jest jego dusza” (Reale, Historia filozofii starożytnej, t. 2, Lublin 1996, 228). W tomie czwartym swojego dzieła autor, który omawia poglądy neoplatoników z IV i V w. po Chr., nie wspomina nawet, że rozumienie człowieka u Platona mogło wydawać się im niejednoznaczne (tamże, t. 4, s. 623-685).

${ }^{12}$ Por. Plato, Phaedo 80E-81A, ed. H.N. Fowler, w: Plato, Euthyphro, Apology, Crito, Phaedo, Phaedrus, London 2005, 280-281, thum. W. Witwicki, w: Platon, Dialogi, t. 1, Kęty 1999, 663-664: „Jeśli się oderwie czysta i żadna cząstka ciała się z nią nie wlecze, bo ona nic wspólnego z nim nie miała za życia dobrowolnie, tylko uciekała odeń i skupiała się sama w sobie, i wciąż o to dbała - a to nic innego nie znaczy, tylko że filozofowała, jak należy i starała się rzeczywiście umrzeć lekko - bo

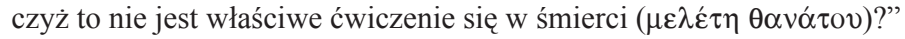

${ }^{13}$ Tenże, Phaedrus, 246C, ed. H.N. Fowler, w: Plato, Euthyphro, Apology, Crito, Phaedo, Phaedrus, s. 482, thum. W. Witwicki, w: Platon, Dialogi, t. 1, s. 140. 
wczesnych i średnich, gdzie zaznaczają się wpływy orfickie, których źródłem były najprawdopodobniej znane Platonowi poglądy pitagorejczyków ${ }^{14}$.

Jednak późne poglądy Platona dostarczają nam już innego obrazu wzajemnych relacji duszy i ciała, a Platon wyraźnie dowartościowuje ciało. O ile w Fedonie i Fajdrosie widzi on ciało tylko i wyłącznie jako przeszkodę dla duszy, o tyle w Timajosie jest ono już współpracownikiem pomagającym duszy w dążeniu do rzeczy boskich. W taki właśnie sposób widzieli poglądy Platona neoplatońscy filozofowie - uważali, że są one niejednoznaczne. Najlepszym przykładem jest tutaj początek fragmentu IV enneady, w którym Plotyn omawia właśnie poglądy na temat nieśmiertelności duszy i zejścia duszy w ciało. Streszczając stanowisko Platona pisze on:

„Okaże się, że nie wszędzie [Platon] mówi to samo - wtedy mógłby ktoś łatwo przejrzeć zamysł mistrza - lecz z jednej strony gardzi wszędzie wszystkim, co zmysłowe, i potępiwszy związek duszy z ciałem powiada, że dusza jest uwięziona i w nim pogrzebana i że ważne jest owo hasło, które powtarzają w misteriach i które głosi, że dusza przebywa w «więzieniu». Także «jaskinia» w jego ustach, podobnie jak w ustach Empedoklesa «grota», oznacza - jak przypuszczam - nasz świat, tam gdzie mówi, że wyzwoleniem z więzów i wyjściem z jaskini dla duszy jest wzlot do umysłowego świata. W Fajdrosie mówi znowu, że powodem przybycia tutaj było «odpadnięcie skrzydeł»; duszę która odeszła w górę, sprowadzają mu nadto tutaj z powrotem ustalone okresy czasu, wyroki zaś zsyłają tu jeszcze dusze inne, a także losy, dopusty i konieczności.

A kiedy w wypowiedziach tych wszystkich potępił przybycie duszy do ciała, to z drugiej strony, mówiąc o świecie naszym w Timajosie wychwala ów świat jako szczęsne bóstwo i powiada, że dusza została dana przez dobrego stwórcę, by świat posiadał umysłową świadomość, ponieważ powinien był posiadać świadomość umysłową, a to stać się nie mogło bez duszy. Więc dlatego Bóg zesłał mu duszę świata, duszę zaś każdego z nas zesłał w tym celu, by świat był doskonały"15.

Powyższy tekst jest nie tylko świadectwem dyskusji, która toczyła się w całej greckiej filozofii, dyskusji wpływów orfickich (deprecjonujących ciało) z wpływami olimpijskimi (dowartościowującymi ciało). Plotyn wyraźnie pokazuje, że Demiurg najpierw dając światu duszę, a następnie „zsyłając nas”, tj. dając każdemu z nas ciało, pragnął doskonałości materialnego świata. Zatem mamy tutaj także do czynienia z przekonaniem, iż cielesność człowieka nie jest pomyłką i jakimś niezrozumiałym zmuszeniem duszy do tego, aby

${ }^{14}$ Por. uwagi Catherine Zuckert (Plato's Philosophers. Coherence of the Dialogues, Chicago 2009, 775-778) na temat występowania poglądów pitagorejskich w Fedonie, gdzie Sokrates pociesza uczniów wobec zbliżającej się swojej śmierci.

${ }^{15}$ Plotinus, Enneades IV 8, 1, ed. P. Henry - H.R. Schwyzer, w: Plotinus, Opera, t. 2, Paris Bruxelles 1951, 228-230, thum. A. Krokiewicz: Plotyn, Enneady IV-V, Warszawa 2000, 492-493. 
zrezygnowała ze swego szczęścia, ponieważ musi ponieść jakąś karę. Zesłanie duszy w ciało służy doskonałości świata materialnego, który nie może jej osiagnąć bez nieustannego kontaktu ze światem intelektualnym. Zasadniczo wszyscy neoplatonicy zgadzali się ze stwierdzeniem, że dusza została właśnie dlatego obdarzona ciałem, ponieważ ma to swoją logikę w porządku kosmosu. Człowiek więc spełnia na tym świecie zadanie wprowadzania ładu, który cechuje świat intelektualny, w rzeczywistość materialną. Tak jak Dusza Świata sprawia, że cały materialny kosmos porusza się i działa wedle ściśle ustalonych reguł, podobnie ma działać dusza człowieka w bardziej szczegółowym zakresie. Oczywiście jest to szczególnie zadaniem człowieka, który rozumie tę rolę duszy w świecie, a więc przede wszystkim filozofa. Filozof wprowadza intelektualny ład w relacje duszy z ciałem, a także w tej cząstce świata, w której żyje ${ }^{16}$.

Wśród neoplatoników jednak nie było zgodności odnośnie do tego, czy wejście preegzystującej duszy w ciało jest wynikiem jej osobistego pragnienia indywidualności (jak to jest w przypadku Plotyna), czy raczej jest to zrządzenie Demiurga, który zarządza światem materialnym (jak to jest w przypadku tych autorów, którzy pozostają pod większym wpływem Platońskiego Timajosa). Zależnie od tych różnic sama ocena ludzkiego ciała jest już zasadniczo inna. Ciało i materialny wymiar człowieka zostają włączone w „logikę” działania wszechświata. Poza tym należy zauważyć, że sam fakt uważania ciała i materialnej rzeczywistości za coś gorszego od duszy i tego, co intelektualne, nie musi wcale oznaczać jednoznacznie negatywnej oceny ludzkiej cielesności.

3. Zejście duszy w ciało i jego konsekwencje. Wszystkie wymienione wyżej rozbieżności w postrzeganiu ciała przez neoplatoników nie wpływają jednak zasadniczo na poglądy odnośnie do tego, jak ma wyglądać istnienie duszy po śmierci. Aby lepiej naświetlić problem, trzeba zastanowić się nad tym, jak było rozumiane samo połączenie duszy z ciałem. Zaznaczmy od razu, że we wszystkich neoplatońskich systemach dusza jest preegzystująca, to znaczy, że istnieje wcześniej, zanim połączy się z ciałem. Jest to oczywiste w przypadku, kiedy neoplatonicy podążają za stwierdzeniami z wczesnych dialogów i przyznają, że dusza jest odwieczna. W przypadku przyjęcia opisu stworzenia świata z Timajosa, w którym dusze są stwarzane przez Demiurga, czyni on to także przed wejściem duszy w ciało i dopiero pomniejsi bogowie dokonują połączenia dusz z ciałami ${ }^{17}$.

${ }^{16}$ Poglądy te były w bardzo ścisły sposób związane z praktykowanymi przez neoplatoników rytuałami teurgicznymi, których celem było podniesienie duszy na drodze doskonałości z tego, co materialne, ku temu, co ponadzmysłowe, ale jednocześnie przywrócenie wprowadzania ładu świata intelektualnego w materialny kosmos. Precyzyjnie pokazuje to G. Shaw (Theurgy and the Soul. The Neoplatonism of Iamblichus, University Park 1995, 129-142).

${ }^{17}$ Por. Reale, Historia filozofii starożytnej, t. 2, s. 227-228. 
Kluczowe dla wyjaśnienia relacji duszy z ciałem jest rozumienie tego, jak i w jakim stopniu dusza schodzi w ciało, czyli to, jak bardzo zatraca swoją intelektualną naturę $\mathrm{w}$ momencie, kiedy to zejście nastapi. Bardzo ściśle łączy się z tym zagadnienie powodu, dla którego dusza łączy się z ciałem. Jeżeli dzieje się to pod wpływem jakiegoś przymusu, czy winy, to w takich przypadkach samo ciało będzie postrzegane negatywnie, ponieważ dusza jest tutaj niejako wyrwana z właściwej sobie noetycznej rzeczywistości. Skoro zaś może się to dziać $\mathrm{z}$ dobrowolnego wyboru, to negatywny wymiar zostaje znacząco zredukowany, a sama dusza, podejmuje się wykonania kosmicznej misji, polegającej na wprowadzaniu ładu intelektualnego świata w rzeczywistość materialną ${ }^{18}$. W tym przypadku zejście duszy w ciało wynika niejako z samej natury wszechświata i nie może być postrzegane negatywnie.

Taką dialektykę pozytywnego i jednocześnie negatywnego postrzegania przyjęcia ciała widzieliśmy już $\mathrm{w}$ Enneadach Plotyna. $Z$ jednej strony pisze on o połączeniu duszy z materią w sposób pozytywny. Dusza Świata jest ostatnią hipostazą ponadzmysłową i dlatego jej naturalnym zadaniem jest właśnie tworzenie materialnego kosmosu poprzez odwzorowywanie doskonałych idei. Dokonuje się to jednak nie tylko dzięki Duszy Świata jako całości, ale także dzięki duszom indywidualnym, ponieważ świat duszy jako całość nie posiada sam w sobie spójności i jedności właściwej wyższym hipostazom ${ }^{19}$.

Innymi słowy indywidualność duszy jest tutaj potrzebna jako naturalny łącznik pomiędzy tym, co jest jednością $w$ świecie intelektualnym i wielością zmysłowej materii. Jednak z drugiej strony Plotyn pisze o tym, że dusza ludzka zstępując $\mathrm{w}$ ciało $\mathrm{w}$ poszukiwaniu indywidualności popełnia swego rodzaju błąd. Przebywanie w intelektualnym świecie zaczyna ją ,nużyć” i właśnie dlatego poszukiwanie indywidualności sprowadza ją w ciało, co jest przez Plotyna oceniane negatywnie ${ }^{20}$. W ten sposób postrzega on nie tylko złe czyny, których dusza dopuszcza się w ciele, ale także sam akt złączenia z ciałem ${ }^{21}$. Wydaje się, że właśnie ta negatywna ocena spowodowała, że Plotyn uważał, iż dusza nie łączy się z ciałem w sposób całkowity ${ }^{22}$. Pozostaje w niej zawsze

${ }^{18}$ Por. A.H. Armstrong - R.A. Marcus, Wiara chrześcijańska a filozofia grecka, thum. H. Bednarek, Warszawa 1964, 58-59.

${ }^{19}$ Por. Plotinus, Enneades IV 8, 7, ed. Henry - Schwyzer, s. 246-248, thum. Krokiewicz, s. $499-500$.

${ }^{20}$ Tamże IV 8, 4, ed. Henry - Schwyzer, s. 236-238, thum. Krokiewicz, s. 496: „I wtedy przychodzi na nią tak zwane «opadnięcie skrzydeł» i jarzmo cielesnej niewoli, gdyż dusza chybiła bezpiecznej przystani w zarządzie tego, co lepsze, jaką miała przy wszechduszy, a było jej przedtem pod każdym względem lepiej, kiedy wzniosła się wzwyż. Więc teraz jest niewolnicą skutkiem swojego upadku, baczną na pęta i działającą w zasięgu postrzegania zmysłowego, ponieważ ma zasadnicze przeszkody w działaniu umysłowym, i mówi się o niej, że leży w grobie i przebywa w jaskini”.

${ }^{21}$ Por. tamże IV 8, 5, ed. Henry - Schwyzer, s. 242, tłum. Krokiewicz, s. 497: „A błąd jest dwojaki: jeden polega na winie zejścia, drugi zaś na dopuszczeniu się tutaj przez duszę złych czynów”.

${ }^{22}$ Por. mój komentarz na temat indywidualności duszy ludzkiej u Plotyna (T. Stępień, $C z y d u$ - 
jakaś część, która nie ma kontaktu z materią, a i ten niecałkowity kontakt będzie posiadał negatywny wydźwięk.

Warto wspomnieć w tym miejscu o poglądach ucznia Plotyna - Porfiriusza, który w kwestii oceny cielesności pozostanie zasadniczo zgodny ze swoim mistrzem. Jednak rozwinie on metafizycznie jego poglądy posługując się schematem istoty, władzy i działania. Porfiriusz twierdzi, że istota duszy po jej zejściu w ciało pozostaje niezanieczyszczona przez materię. Posiada ona bowiem dwie władze ( $\delta v v o ́ \mu \varepsilon \imath \varsigma)$, z których jedna umożliwia wykonywanie działań intelektualnych, a druga jest skierowana ku zmysłom. Jej „styczność” z ciałem jest możliwa dzięki tej drugiej władzy, umożliwiającej wykonywanie

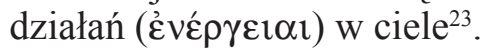

$\mathrm{Z}$ naszego punktu widzenia najciekawsze są jednak poglądy Jamblicha, który w kwestii zstapienia duszy w materię zajmie przeciwne stanowisko. To, co ma on do powiedzenia, jest tym bardziej istotne, że traktat $O$ duszy jest dziełem, które w sposób bardzo znaczący wpłynęło na dalszy rozwój poglądów neoplatoników w tej materii. Jego podstawowym celem było nie tylko przedstawienie własnej doktryny Jamblicha dotyczącej duszy, ale także polemika z neoplatońskimi poprzednikami, przede wszystkim z Plotynem i Porfiriuszem ${ }^{24}$. Polemiczny charakter dzieła sprawia, że nawet $\mathrm{w}$ zachowanych fragmentach znajdziemy katalog filozoficznych poglądów na temat duszy, jej zstąpienia w ciało i losów po śmierci.

Ponieważ Jamblich był w dużo większym stopniu przekonany o tym, że poglądy Platona i Arystotelesa są ze sobą zgodne, przyjął on w dużej mierze arystotelesowski sposób rozumienia duszy, która jest aktem ciała ${ }^{25}$. Nie oznaczało to jednak pominięcia platońskiego zejścia duszy w ciało. Jamblich po prostu uznał, że dusza łączy się z ciałem w sposób całkowity tracąc odniesienie do świata intelektualnego ${ }^{26}$. W zachowanych fragmentach dzieła $O$ duszy Jamblich zajmuje się zarówno zstappieniem duszy w ciało, jak i śmiercią oraz eschatologicznymi losami duszy. Filozof zauważa, że wśród jego poprzedników nie ma zgodności odnośnie do tego, gdzie dusza przebywa przed zejściem

sza ludzka jest indywidualna? Kontrowersje wokót rozumienia duszy w starożytnym neoplatonizmie niechrześcijańskim, SPCh 48 (2012) nr 1, 89-93).

${ }^{23}$ Por. A. Smith, Porphyry's Place in Neoplatonic Tradition, Hague 1974, 8-9.

${ }^{24}$ Zachowane fragmenty dzieła Jamblicha zebrali J.F. Finamore i J.M. Dillon, opatrując je przedmową i obszernym komentarzem (Iamblichus, De anima. Text translation and commentary, ed. J.F. Finamore - J.M. Dillon, Leiden - Boston - Köln 2002). Odnośnie do celu napisania dzieła zob. tamże, s. 10.

${ }^{25}$ Por. Shaw, Theurgy and the soul, s. 95.

${ }^{26}$ Jamblich przeciwstawia się Plotynowi, który twierdził, że natura duszy w momencie zejścia w ciało pozostała zasadniczo nie naruszona. Ponieważ według Jamblicha dusza łączy się z ciałem, całkowicie następuje zmiana w jej istocie, powodująca, że traci ona pierwotną nieśmiertelność, por. C. Steel, The Changing Self. A Study on the Soul in later Neoplatonism: Iamblichus, Damascius and Priscianus, Brussel 1978, 39-44). 
w ciało, czy jest to miejsce ponad sferami nieba, w sferach nadksiężycowych, czy też w podlegającej powstawaniu i ginięciu sferze podksiężycowej ${ }^{27}$. Jamblich rozwija tutaj swoją własną teorię interpretując w sposób specyficzny opis stworzenia duszy z Platońskiego Timajosa. Uważa on, że zstapienie duszy w ciało dokonuje się w kilku etapach i to zależnie od rodzaju duszy o jakim mowa, duszy boskiej czy ludzkiej ${ }^{28}$. Nie wchodząc jednak w zbyt szczegółowe rozróżnienia, możemy stwierdzić, że we wszystkich przypadkach dusza zawsze jest preegzystująca w stosunku do ziemskiego ciała ${ }^{29}$. Jamblich podaje również powody, dla których dusza zstępuje w ziemskie ciało. Tutaj także, podobnie jak w przypadku Plotyna, możemy zaobserwować dwa wymiary postrzegania tego procesu. Po pierwsze, dusza zstępuje w ciało zgodnie z prawami rządzącymi kosmosem. Dopiero w drugiej kolejności Jamblich zajmuje się tym, czy dusza przyjmuje ciało z konieczności czy na skutek swojej wolnej decyzji. Jak podkreślają John F. Finamore i John Myles Dillon, Jamblich nie uważa tych dwóch sposobów postrzegania tego procesu za sprzeczne ze sobą, ale raczej uważa, że są one komplementarne ${ }^{30}$. Zatem Demiurg tworząc kosmos po prostu zaplanował zejście duszy w ciało jako całkowicie naturalny proces. Jednak nie znaczy to wcale, że dusza zawsze zapoczątkowuje ten proces $\mathrm{z}$ takich samych powodów. Jamblich opisuje to w następujący sposób:

„Myślę, że powody dla których dusze zstępują są różne i że sprawiają one także różnice w sposobie zejścia. Albowiem dusza, która schodzi dla zbawienia, oczyszczenia i udoskonalenia tego świata, jest nieskalana w swoim zejściu. $\mathrm{Z}$ drugiej strony dusza, która kieruje się ku ciału dla ćwiczenia i poprawienia swojego charakteru, nie jest całkowicie wolna od namiętności i nie została odesłana jako wolna. Dusza, która schodzi tutaj dla odbycia kary i sądu, wydaje się być w pewien sposób ściagnięta i zmuszona".

Niektórzy z bardziej współczesnych filozofów, a zwłaszcza Kroniusz, Numeniusz, Harpokrates i ich szkoły, nie czynią tych rozróżnień, ale, wobec braku wyróżniających kryteriów, łączą wcielenie wszystkich dusz w jeden rodzaj i utrzymuja, że każde wcielenie jest złe"31.

Widzimy zatem, że Jamblich zupełnie świadomie dopuszcza taki rodzaj zejścia duszy w ciało, który jest dobry, przeciwstawiając się jednocześnie tym filozofom, którzy każdy rodzaj połączenia z ciałem uważają za zły. Doskonałe dusze łączą się z ciałami dlatego, aby zbawiać i udoskonalać świat materialny.

${ }^{27}$ Por. Iamblichus, De anima 26, ed. Finamore - Dillon, s. 53-55, komentarz, s. 149.

${ }^{28}$ Por. tamże, komentarz, s. 152.

${ }^{29}$ Nie podejmuję tutaj tematu ,wehikułu duszy”, ponieważ problem ten wydaje się wykraczać poza omawiane zagadnienia. Problem ten został wyczerpująco opracowany przez J.F. Finamore'a (Iamblichus and the Theory or the Vehicle of the Soul, Chico 1985), gdzie także wyjaśnia on teorię budowy wehikułu duszy i jego przeznaczenie (tamże, s. 11-32).

${ }^{30}$ Por. Iamblichus, De anima 26, ed. Finamore - Dillon, s. 53-55, komentarz, s. 153.

${ }^{31}$ Por. tamże 29, ed. Finamore - Dillon, s. 56, tłum. własne. 
Te mniej doskonałe są tylko w pewien sposób do tego zmuszone, ponieważ zejście w ciało jest dla nich szansą zapanowania nad namiętnościami. Jedynie ostatni rodzaj dusz podlega przymusowi, ponieważ dla nich przebywanie w ciele jest sądem i karą. Takie poglądy Jamblicha na temat zejścia duszy $\mathrm{w}$ ciało łączą się z pewnością z drugą częścią jego nauczania, dotyczącą tego, w jaki sposób dusza może uzyskać oczyszczenie i powrócić do doskonałego stanu. Jamblich twierdzi, że jest to możliwe dzięki praktykom teurgicznym, czyli specjalnej formie rytuałów, których celem jest właśnie oczyszczenie duszy i podniesienie jej do noetycznej rzeczywistości. Jest to możliwe dzięki używaniu symboli, które są miejscami obecności bogów w świecie, ponieważ przez tych bogów zostały rozsiane w momencie, kiedy świat został utworzony. Poprzez rytuały wykorzystujące specyficzne minerały, kwiaty i zwierzęta, aż do wyższych form, które zawierają dźwięki, boskie imiona i liczby, dusza neoplatońskiego filozofa może zostać przywrócona do boskiej rzeczywistości i odzyskać utraconą przez wejście w ciało nieśmiertelność ${ }^{32}$.

Pod koniec swego traktatu Jamblich zajmuje się losami duszy po śmierci. Po tym jak podlegają one sądowi, karze i oczyszczeniu otrzymują nagrodę. Przedstawia on znów wiele poglądów swoich poprzedników na temat tego, jaki jest ostateczny status duszy i na czym polega ich nagroda $(\dot{\varepsilon} \pi \iota \kappa \alpha \rho \pi i \alpha)^{33}$. Znów przedstawia on poglądy swoich poprzedników, które w zasadzie polegają na różnych interpretacjach postrzegania Hadesu przez samego Plato$n^{34}$. Pośród różnych pojawiających się opinii, Jamblich zdaje się przychylać do tej, zgodnie z którą oczyszczona dusza zajmuje miejsce pośród aniołów

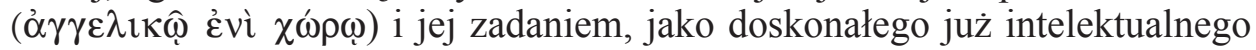
jestestwa, pozostaje opieka nad materialnymi bytami pozbawionymi duszy ${ }^{35}$. Co jednak najbardziej istotne dla naszych rozważań, dusze po śmierci przebywają w doskonałej rzeczywistości pośród bytów boskich zawsze bez ziemskiego materialnego ciała. One właśnie dlatego mogą podjąć się opieki nad światem materialnym, ponieważ same nie mają już w swojej naturze kontaktu z tym, co zmysłowe.

Analizując poglądy neoplatoników na temat duszy nie możemy nie zatrzymać się nad pismami Proklosa, które z pewnością dobrze znał Pseudo-Dionizy Areopagita. Twierdzenia Proklosa w tej materii można uznać za połączenie wcześniejszych neoplatońskich rozważań, z tym jednak zastrzeżeniem, że powraca on do Plotyńskiej koncepcji, iż dusza pozostaje niezmieniona w momencie połączenia $\mathrm{z}$ ciałem ${ }^{36}$. $\mathrm{Z}$ jednej strony twierdzi on, że dusza rozumna

${ }^{32}$ Hierarchia symboli i ich znaczenie w praktykach teurgicznych wyjaśniłem w moim artykule dotyczącym tej problematyki (T. Stępień, Rola symbolu w filozofii neoplatońskiej, STV 45 (2007) nr 2, 79-95).

\footnotetext{
${ }^{33}$ Por. Iamblichus, De anima 47-53, ed. Finamore - Dillon, s. 73-75.

${ }^{34}$ Por. tamże, komentarz, s. 205.

${ }^{35}$ Por. tamże, komentarz, s. 207-211.

${ }^{36}$ Por. Steel, The Changing Self, s. 74-75.
} 
W swej istocie pozostaje niezanieczyszczona materią, ale także uznaje, że do jej uwolnienia potrzebne jest rytualne oczyszczenie, czyli praktyki teurgiczne. Dusza posiada zatem wieczną substancję (ov̉oí $\alpha$ ), która nie podlega zmianom, a zarazem czasowe i zmienne działanie ( $\dot{\varepsilon} v \varepsilon \dot{\varepsilon} \rho \gamma \varepsilon 1 \alpha$ ). Jak słusznie zauważa Gregory Shaw, tekst ten jest świadectwem, że Proklos uważał, iż dusza nie jest jedną całościa, lecz składa się z części. Diadoch ateńskiej szkoły precyzuje swoje stanowisko pokazując, jak następuje proces zstępowania i wstępowania duszy. Zstępując w ciało dusza przybiera coraz to niższe postaci materialnych osłon i, co za tym idzie, coraz niższe części duszy. Wstępując zaś na powrót do intelektualnego świata pozbywa się władz, które jej były potrzebne w wędrówce ku dołowi i do narodzenia się w ciele:

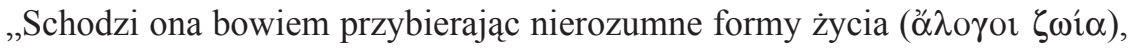
wstępuje zaś, zdejmując z siebie wszystkie moce twórcze ( $\gamma \varepsilon v \varepsilon \sigma i o v p \gamma o i ̀ ~$ $\delta v v \alpha ́$ $\mu \varepsilon ı \varsigma)$, które otaczały ją podczas schodzenia, stając się czysta i pozbawiona wszystkich władz, które są niezbędną pomocą w procesie powstawania"37.

Dusza więc wznosząc się dzięki praktykom teurgicznym uzyskuje niezależność od tych niższych części, które umożliwiają jej połączenie z ciałem. Jasne jest więc, że jej ostateczne szczęście jest stanem, w którym nie tylko nie posiada ziemskiego ciała, ale nawet swoich niższych części - zmysłowej i wegetatywnej, które są jej niepotrzebne do szczęścia w stanie nieśmiertelności.

Na koniec rozważań dotyczących poglądów neoplatoników na temat duszy i jej zejścia w ciało warto poczynić jeszcze jedną uwagę odnośnie Damaskiosa i Pryskianosa. Jak twierdzi Carlos Steel ci ostatni neoplatonicy żyjący w okresie zamknięcia szkoły w Atenach (529 r. po Chr.) w zasadzie rozwijali koncepcję Jamblicha przeciwstawiając się Proklosowi ${ }^{38}$. Ostatecznie więc wpływ Jamblicha okazał się decydujący, a wraz z nim powraca przekonanie o pozytywnej roli materialnego świata $\mathrm{w}$ procesie uzyskiwania przez duszę doskonałości.

Podsumowując można stwierdzić, że niezależnie od tego, jak neoplatonicy pojmowali połączenie duszy z ciałem, to jednak zawsze do osiagnnięcia pełnego szczęścia po śmierci potrzebne są człowiekowi oczyszczające rytuały. To właśnie konieczność stosowania teurgicznych rytów jest najlepszym świadectwem tego, z jak wielkim szacunkiem podchodzili oni do cielesnej materii. Choć nie ma tu miejsca, aby bardziej szczegółowo omówić znaczenie owych rytuałów, to jednak trzeba choć krótko zaznaczyć, że ich skuteczność płynęła nie z ludzkich możliwości, ale raczej z tego, że wykorzystywano w nich części materialnych bytów, w których, jak wierzono, zawarta jest moc bogów. Zatem bogowie stwarzając rzeczywistość uważali materialny świat za naturalną cząstkę kosmosu i dlatego zostawili w niej pewne odpryski swojej mocy, które były

${ }^{37}$ Proclus, Institutio theologica 209, ed. E.R. Dodds, Oxford 1992, 182, thum. R. Sawa: Proklos, Elementy teologii, Warszawa 2002, 132.

${ }^{38}$ Por. Steel, The Changing Self, s. 18-19. 
ukryte $\mathrm{w}$ symbolach odpowiadających specyficznym dla nich przymiotom. I tak na przykład moc boga słońca była na ziemi zawarta w pewnych rodzajach przejrzystych minerałów, w kwiatach, które podążają za słońcem (heliotrop), czy w końcu w zwierzętach solarnych, jak lew czy kogut ${ }^{39}$. Materialny świat był więc miejscem obecności i działania bogów, a zatem nie mógł być postrzegany jako niepotrzebny dodatek, tylko jako integralna część całego kosmosu.

Dla naszych rozważań jednak najważniejszy jest fakt, że mimo, iż w neoplatonizmie obserwujemy tak znaczące dowartościowanie materialnej rzeczywistości, to jednak zawsze ostateczne szczęście duszy po śmierci wiązało się z uwolnieniem jej spod wpływów ziemskiego ciała. Najlepiej świadczy o tym właśnie powszechne przyznawanie konieczności sprawowania teurgicznych rytuałów oczyszczających.

4. Metempsychoza. Ostatnim problemem, który pojawia się w neoplatońskiej wizji losów człowieka po śmierci, jest zagadnienie metempsycho$\mathrm{zy}^{40}$. Neoplatonicy nie poświęcają jej wiele miejsca, ale widać w ich tekstach stwierdzenia, które pokazują, że dusza człowieka osiaga swoją doskonałość właśnie poprzez działania wykonywane podczas przebywania w ciele. Jamblich jednoznacznie twierdzi, że ostatecznie swoje przeznaczenie doskonała dusza osiagnie w oddzieleniu od ciała materialnego, a w warunkach doskonałego życia będzie jej mogło towarzyszyć jedynie ciało eteryczne, będące doskonałym wehikułem duszy posiadającym kolisty kształt ${ }^{41}$. Zatem ciało materialne jako takie jest częścią człowieka tylko przejściowo, dopóki dusza nie osiagnie ostatecznej doskonałości. Jednak pozytywny stosunek do materii wyraża się u Jamblicha właśnie tym, że dusza może wstępować w ciało z własnej woli. Jak widzieliśmy wyżej, dusze, które już były wolne i osiagnęły doskonałość, zstępowały w ciała, aby wprowadzać ład w materialnym świecie i w sposób doskonały wypełniać wolę bogów. Jednak nawet duszom niedoskonałym zstąpienie w ciało było potrzebne, aby mogły pracować nad osiagnięciem doskonałości. Nie ma w tym miejscu pewności, czy ten proces dokonuje

\footnotetext{
${ }^{39}$ Por. Shaw, Theurgy and the Soul, s. 49.

${ }^{40}$ Ponieważ dyskusja chrześcijańskich autorów z greckimi poglądami dotyczącymi reinkarnacji wykracza poza ramy niniejszego artykułu, ograniczę się tutaj tylko do poglądów samych neoplatoników. Ze względu na fakt, że pogląd o reinkarnacji posiada swoje orfickie korzenie, najlepszym opracowaniem, które rzuca światło na tę kwestię jest opracowanie M.H. de Jáuregui, Orphism and Christianity in Late Antiquity, Berlin - New York 2010, spec. 20, 134 i 213-217. Należy także wspomnieć, że niektórzy autorzy widzą we fragmentach dzieła Porfiriusza Przeciwko chrześcijanom, w których przeciwstawia się on nauce o zmartwychwstaniu ciał (Porphirius, Contra Christianos 24A-B, wyd. grecko-polskie, tekst grecki i oprac. A. Caba, thum. P. Ashwin-Siejkowski: Porfiriusz, Przeciw chrześcijanom, Kraków 2006, 154-159, właśnie obronę neoplatońskiego poglądu o reinkarnacji (H.J. Blumenthal, Soul and Intellect. Studies in Plotinus and Later Platonism, Aldershot 1993, s. 60).

${ }^{41}$ Por. Shaw, Theurgy and the Soul, s. 91.
} 
się poprzez jedno, czy wiele wstapień duszy w ciało, jednak niezaprzeczalny pozostaje fakt, że dusza może osiąnnąć swoją pełną doskonałość i wypełnić niejako swoje kosmiczne przeznaczenie tylko poprzez wejście w ciało i to na pewno więcej niż jednokrotnie.

Zadanie, które dusza ma do spełnienia w ciele, nie jest jednak potrzebne tylko jej samej, ponieważ ona także urzeczywistnia wprowadzanie intelektualnego ładu w materialny chaos, a to oznacza, że wejście duszy w ciało jest także potrzebne dla właściwego funkcjonowania kosmosu. Dlatego właśnie neoplatonicy za Platonem ${ }^{42}$ przyznają, że metempsychoza jest możliwa i nawet konieczna zarówno dla samej duszy, jak i spełniania przez nią w kosmosie roli, która została jej wyznaczona przez bogów. Wiemy także, że niektórzy z nich uważali się za powtórnie wcielonych wcześniej żyjących wielkich filozofów. I tak na przykład Proklos twierdził, że jest reinkarnacją Nikomachusa ${ }^{43}$.

Pojawił się jednak także i pogląd, że dusze wybranych filozofów mogą osiagnąć taki poziom doskonałości, który pozwoli im na wyrwanie się z kręgu powtórnych wcieleń. Jednak i tutaj nie było wśród ostatnich pogańskich filozofów całkowitej zgodności. Porfiriusz, jak się wydaje, dopuszczał taką możliwość, podczas gdy Syrianos, Proklos i Damaskios całkowicie ją odrzucali. Zwłaszcza doskonałe dusze teurgów nie mogły wiecznie pozostawać w świecie intelektualnym, gdyż z logiki działania kosmosu wynikało ich nieustanne powracanie, aby zapewnić porządek zmysłowemu światu ${ }^{44}$.

\section{Chrześcijańska transformacja nauki o duszy u Pseudo-Dionizego.} Możemy teraz wrócić do samego Pseudo-Dionizego Areopagity i jego polemicznego tekstu, wyciągając wnioski odnośnie do chrześcijańskiego charakteru jego poglądów na temat losów człowieka po śmierci. Po pierwsze, jak widzieliśmy wyżej, w poglądach neoplatoników nie znajdziemy nigdzie twierdzenia, że ziemskie ciało ma towarzyszyć duszy w jej pośmiertnym przebywaniu w doskonalszym świecie. Pseudo-Dionizy ma najwyraźniej świadomość, że prawda o zmartwychwstaniu ciał jest całkowicie sprzeczna z neoplatońskim widzeniem losów duszy po śmierci, ponieważ kilkakrotnie uzasadnia, dlaczego chrześcijanie przyjmują taki pogląd. Już na początku VII rozdziału traktatu Hierarchia kościelna pisze on:

„Oczyszczone ciała tych świętych dusz, dźwigające to samo brzemię i pielgrzymujące razem z nimi, przypisane sobie nawzajem i razem z nimi zmagające się w życiowych zapasach, otrzymają nagrodę za swoje wielkie trudy w służbie Boga i będą się radować własnym zmartwychwstaniem i tym

${ }^{42}$ Por. Blumenthal, Soul and Intellect, s. 60.

${ }^{43}$ Por. Shaw, Theurgy and the Soul, s. 200.

${ }^{44}$ Por. S.R.P. Gertz, Death and Immortality in Later Platonism. Study on the Ancient Commentaries on Plato's ,Phaedo”, Leiden - Boston 2011, 187-188. Zob. także Iamblichus, De anima, komentarz, 206. 
samym przypadające $\mathrm{w}$ udziale duszom, nie podlegającym zmianom boskim życiem. Zjednoczone ze świętymi duszami, których towarzyszami były w ciagu życia, staną się jakby «członkami Chrystusa» (por. 1Kor 6, 15; Ef 5, 30; Rz 12, 5) i będą się radować nieśmiertelnością i szczęśliwością ich nienaruszalnego podobieństwa do Boga" ${ }^{45}$.

Dalej zaś, w części poświęconej kontemplacji i podaniu właściwego znaczenia obrzędu namaszczenia ciała zmarłego olejem, dopowiada:

„Jeżeli zmarły i cieleśnie, i duchowo przeżył życie, podobając się Bogu, to jego ciało - towarzyszące zawsze duszy w jej świętych zmaganiach - zasługuje na te same zaszczyty, które przypadają duszy. Oto dlaczego boska sprawiedliwość w ostatecznym rozrachunku ofiarowuje tak duszy, jak związanemu z nią ciału, stosowne nagrody - ponieważ ciało brało udział w tej samej co dusza wędrówce po drogach czy to świętości, czy to bezbożności. Stąd boskie prawo obdarowuje i jedno, i drugie łaską uczestnictwa w świętych rzeczach przez komunię z Boską Zwierzchnością: duszę przez czystą kontemplację i wiedzę o świętych sakramentach, ciało symbolicznie przez namaszczenie najświętszym olejem i w najbardziej boskich symbolach boskowładnej komunii. Tak więc człowiek w całej swojej pełni zostaje uświęcony i dzieło jego zbawienia dopełnia się święcie, i przez to zupełne oczyszczenie daje się mu do zrozumienia, że jego zmartwychwstanie będzie również najbardziej całościowe" ${ }^{\sharp 6}$.

Podstawowym zatem argumentem Pseudo-Dionizego jest to, iż ciało tak samo jak dusza uczestniczy w ziemskim dążeniu człowieka do nieba. Zauważmy, że nie tylko bierze ono udział w różnego rodzaju umartwieniach i ćwiczeniach ascetycznych, ale także ma ono swój udział w sakramentalnych rytach. Ono już w liturgii Kościoła zostaje uświęcone - człowiek zostaje uświęcony w całej pełni, a więc także w swoim cielesnym wymiarze.

Skoro to samo ciało ma doznać także wiecznej nagrody, a wieczne życie ma mieć miejsce dopiero po „czekającym w przyszłości pełnym zmartwychwstaniu” ${ }^{47} \mathrm{i}$, ponownych narodzinach" ${ }^{48}$ (jak Dionizy też określa zmartwychwstanie ciała), jasne jest, dlaczego nie może być mowy o ponownym zejściu duszy w jakieś inne ciało i odrzucona musi być także metempsychoza. Dusza bowiem cieszy się szczęściem nieba wraz z ciałem, które towarzyszyło jej na ziemi, a człowiek jest tak samo złożony z duszy i ciała jak na ziemi. W takim ujęciu metempsychoza wprowadzałaby niemożliwy do przezwyciężenia problem, które z ziemskich ciał miałoby wraz z duszą cieszyć się wiecznym

${ }^{45}$ Pseudo-Dionysius Areopagita, De ecclesiatica hierarchia VII 1, 1, 553A-B, ed. Heil - Ritter, s. 120-121, thum. Dzielska, s. 202-203.

${ }^{46}$ Tamże VII 3, 9, 565B-C, ed. Heil - Ritter, s. 129-130, thum. Dzielska, s. 212.

${ }^{47}$ Tamże VII 1, 1, 553A, ed. Heil - Ritter, s. 120, thum. Dzielska, s. 202.

${ }^{48}$ Tamże VII 3, 1, 557 A, ed. Heil - Ritter, s. 123, tłum. Dzielska, s. 205. 
szczęściem. Musiałaby ona także utracić całkowicie związek z ciałem, w którym przebywała wcześniej. Pseudo-Dionizy zaś przeciwstawia się poglądowi, że po śmierci następuje całkowite zerwanie więzów, jakie na ziemi łączyły duszę z ciałem. Nie czyni tego jedynie poprzez umieszczenie owego poglądu wśród odrzucanych twierdzeń bezbożników, ale nieco wcześniej, opisując znaczenie sakramentu chrztu, argumentuje w następujący sposób:
„Dla nas bowiem śmierć nie oznacza, jak wyobrażają sobie niektórzy, rozpadu

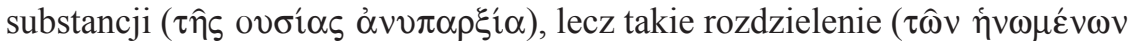

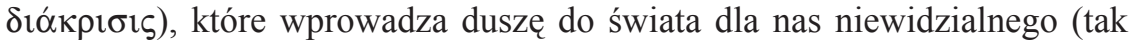 jakby zawsze była pozbawiona ciała), podczas gdy ciało, umieszczone - jeśli można tak powiedzieć - w ziemi, podlega innego rodzaju przemianie, mia- nowicie cielesnej, w której zatraca swoją ludzką formę. Dlatego właśnie owo całkowite zanurzenie ciała $\mathrm{w}$ wodzie jest obrazem śmierci i wiecznego po- chówku ciała. I w tej symbolicznej nauce ten, kto podczas chrztu jest trzy- krotnie zanurzany w wodzie, uczy się mistycznie naśladować śmierć przyna- leżną Boskiej Zwierzchności - tak dalece, jak jest dane ludziom naśladować Boga - śmierć, która była podczas trzech dni i trzech nocy grobem Jezusa - Dawcy Życia; jeżeli jest prawdą, co mówi o Jezusie sekretna i utajona tra- dycja Pisma, że «Władca tego świata nie znalazł w nim niczego własnego» (J 14, 30; 16, 11)"49.

Kluczowe jest tutaj stwierdzenie Pseudo-Dionizego, że śmierć nie oznacza rozpadu substancji, ale pewne „rozdzielenie jedności”. Dusza jest tylko jakby pozbawiona ciała, podczas gdy naprawdę ta łączność $\mathrm{z}$ ciałem w niej pozostaje. Areopagita usiłuje więc wyjaśnić śmierć chrześcijanina na podobieństwo śmierci Chrystusa z tą jednak różnicą, że podczas gdy ciało każdego człowieka w ziemi ,zatraca ludzką formę”, ciało Chrystusa nie uległo rozkładowi. Powyższy fragment mówi więc wyraźnie o innym niż u neoplatoników rozumieniu śmierci i to wyrażonym przy pomocy filozoficznej terminologii.

Jasne jest zatem, dlaczego Pseudo-Dionizy odrzuca drugi i trzeci pogląd „bezbożników” przytaczany na początku rozdziału, czyli pogląd o całkowitym odłączeniu duszy i ciała po śmierci, oraz pogląd o metempsychozie. W polemicznym kontekście może również znaleźć wyjaśnienie ostatnie odrzucone przez Areopagitę twierdzenie o tym, że życie po śmierci wygląda dokładnie tak samo jak życie ziemskie, a „,najbardziej uświęcony spokój doskonałej szczęśliwości, obiecany świętym, odpowiada poziomowi naszego ziemskiego życia [...]" ${ }^{50}$. Być może jest to stwierdzenie skierowane właśnie przeciw pogańskim neoplatonikom, którzy drwiąc z chrześcijańskiej prawdy o zmartwychwstaniu ciał uważali, że nauczanie to oznacza po prostu powrót

\footnotetext{
${ }^{49}$ Tamże II 3, 7, 404B-C, ed. Heil - Ritter, s. 77-78, tłum. Dzielska, s. 154.

${ }^{50}$ Tamże VII 1, 2, 553C, ed. Heil - Ritter, s. 121, thum. Dzielska, s. 203.
} 
do pierwotnego stanu ziemskiego życia ${ }^{51}$. Właśnie dlatego należy odrzucić to przekonanie, ponieważ w warunkach materialnej zmienności i ,posilania się pokarmem właściwym dla życia podlegającego zmianie" nie można mówić o szczęściu mającym trwać na wieki. Choć nie znajdziemy u Pseudo-Dionizego dokładniejszego wyjaśnienia tego, jaki status będzie miało pojmowane w chrześcijański sposób ciało po zmartwychwstaniu, to jednak stara się on w pewien sposób określić, czym różni się szczęśliwe życie po „ponownych narodzinach" od życia na ziemi. Ogólnie mówi on, że będzie to życie w stanie równości z aniołami ${ }^{52}$, oraz życie, w którym zbawiony dostapi ,„pełni pokoju, który niesie ze sobą upodobnienie do Chrystusa" ${ }^{53}$.

$$
* * *
$$

Podsumowując możemy stwierdzić, że analiza neoplatońskich poglądów dotyczących relacji duszy do ciała i losów duszy po śmierci pokazała, iż samo dowartościowanie ludzkiego ciała i materialnej rzeczywistości, nie jest jeszcze cechą wyróżniającą poglądy chrześcijańskie. Oczywiście twierdzenie o zmartwychwstaniu ciał i tym, że to nie sama dusza cieszy się szczęściem po śmierci, ale cały człowiek - dusza i ciało, sprawia, że cielesność jako taka zyskuje jeszcze większą wartość. Dionizy jednak broni się przed stwierdzeniem, że ciało po zmartwychwstaniu będzie dokładnie takie samo, jak ciało ziemskie. Będzie ono przecież wolne od śmierci i ziemskiej zmienności. Jednak najważniejsze jest tutaj stwierdzenie, że będzie to właśnie to samo ciało, czyli nie jakieś inne ciało eteryczne, ale właśnie ciało ziemskie, które zmartwychwstanie i zostanie $\mathrm{w}$ jakiśs sposób przemienione.

Zatem linia oddzielająca poglądy neoplatoników pogańskich i chrześcijan leży właśnie w miejscu, w którym ci drudzy zaczynają nauczać o zmartwychwstaniu ciał. Kluczowe jest więc tutaj zmartwychwstanie, którego przyjęcie także skutkuje twierdzeniem, że dusza nigdy, nawet będąc już oddzielona, ale jeszcze przed zmartwychwstaniem, nie traci całkowicie łączności z ziemskim ciałem. Taki pogląd, który - jak widzieliśmy - utrzymywał również Pseudo-Dionizy, sprawia, że całkowicie niemożliwe jest także pogodzenie chrześcijańskiej

${ }^{51}$ Bardzo przypomina to polemikę Porfiriusza z dzieła Przeciw chrześcijanom ośmieszającą prawdę o zmartwychwstaniu ciał. Porfiriusz przytacza tutaj szereg argumentów, które mają pokazać, że niemożliwe jest zebranie w dniu zmartwychwstania tej samej materii, z której na ziemi było złożone ciało człowieka. Jest tak dlatego, że ciała ludzi po ich śmierci zostają włączone w cykl przyrody, kiedy np. zostają pożarte przez ryby, które z kolei staną się pokarmem dla innych drapieżników (Porphyrius, Contra Christianos 24 A, ed. i tłum. Ashwin-Siejkowski, s. 156-157). Jasne jest, że Porfiriusz traktuje ciało ludzkie po zmartwychwstaniu dokładnie tak samo, jak ciało ziemskie przed zmartwychwstaniem, skoro miałoby być zbudowane z tej samej ziemskiej materii.

${ }^{52}$ Por. Pseudo-Dionysius Areopagita, De ecclesiatica hierarchia VII 1, 2, 553C, ed. Heil - Ritter, s. 121, tłum. Dzielska, s. 203.

${ }^{53}$ Tamże VII 1, 2, 553D, ed. Heil - Ritter, s. 121, thum. Dzielska, s. 203. 
koncepcji duszy z nauką o wędrówce dusz. Odrzucenie metempsychozy jest więc podyktowane zmianą $w$ postrzeganiu samej natury duszy ludzkiej, a więc zmianą ontologiczną, czego świadomość ma sam Areopagita.

Jest także bardzo znamiennym fakt, że właśnie nauczanie o zmartwychwstaniu doprowadziło do odrzucenia nauczania św. Pawła na ateńskim Areopagu. Kiedy św. Paweł wypowiedział naukę o zmartwychwstaniu Chrystusa ,jedni się wyśmiewali, a inni powiedzieli: «Posłuchamy cię o tym innym razem»" (Dz 17, 32). Rzuca to nieco światła na pytanie, dlaczego nieznany bliżej uczeń ateńskiej szkoły neoplatońskiej nawrócony na chrześcijaństwo w połowie V w., pisząc swoje dzieła przybrał pseudonim właśnie Dionizego Areopagity - jednego z tych, którzy przyjęli wtedy orędzie głoszone przez św. Pawła.

\section{HUMAN BODY AND ITS PARTICIPATION IN HEAVENLY HAPPINESS - CONCEPTION OF PSEUDO-DIONYSIUS THE AREOPAGITE AGAINST THE TEACHING OF PAGAN NEOPLATONIC PHILOSOPHERS}

\section{(Summary)}

In seventh chapter of his On the Ecclesiastical Hierarchy Pseudo Dionysius the Areopagite treats on the ceremony of burial. While explaining the rites he makes a few remarks on the Christian understanding of the body and its fate after death, and how it is inconsistent with some pagan views on the matter. He discusses several opposite statements of the complete disintegration of the body, metempsychosis and seeing the life of the body after death exactly like the life on earth (On the Ecclesiastical Hierarchy VII 3, 1).

This polemic is pointed against Neoplatonic philosophers who held such opinions, and to understand the difference between pagan and Christian view on the matter, the second part of the article considers the Neoplatonic view of the life after death. At Neoplatonic schools there were a different opinions of whether the embodiment is good or rather damaging to the intellectual soul. Philosophers like Plotinus and Porphyry explained descend of the soul as being evil, while Iamblichus and Damaskios thought otherwise. However there were points in which Neoplatonics were completely in agreement. All of them admitted that the happiness of the soul after death is possible only without the material body, and that the soul can reincarnate. Analysis of Neoplatonic view shows that the negative approach to the body is not the feature that could be ascribed to all Late Greek philosophers.

Pseudo-Dionysius sees the problem in the Christian perspective. The soul at the moment of death does not loose completely the connection with the body and thus death does not mean the dissolution of the substance. However the new body that will be given to believers after resurrection will not be exactly the same with the earthly one. 
Key words: Pseudo-Dionysius the Areopagite, body, Neoplatonism, soul, descent of the soul.

Słowa kluczowe: Pseudo-Dionizy Areopagita, ciało, neoplatonizm, dusza, połączenie duszy z ciałem. 